\title{
The influence of ammonia and amines on grass silage intake and intake behaviour in dairy cows
}

\author{
M van Os $\dagger$, JP Dulphy *, R Baumont \\ with technical collaboration of M Jailler and JM Ballet \\ INRA-Theix, Station de Recherches sur la Nutrition des Herbivores, \\ 63122 Saint-Genès-Champanelle, France
}

(Received 9 November 1993; accepted 15 April 1994)

\begin{abstract}
Summary - The influence of ammonia $\left(\mathrm{NH}_{3}\right)$ and amines on silage dry matter intake (DMI) and milk yield was studied in 4 rumen-cannulated dairy cows. Four dietary treatments were studied: a direct-cut grass silage without additive (WAS); a formic acid $(4.5 \mathrm{l} / \mathrm{t})$ preserved silage from the same sward (FAS); and FAS with addition, just before feeding, of either $2.9 \mathrm{~g} \mathrm{NH}_{3} / \mathrm{kg}$ dry matter (DM) (FAS $+\mathrm{N}$ ) or $2.8 \mathrm{~g}$ amine/kg DM (FAS + A). In 3 successive cross-over design experiments, the diets WAS, FAS + $\mathrm{N}$ and FAS + A were compared to the control diet FAS. Daily DMI was lower $(P<0.10)$ for WAS, and the milk yield also tended to be lower. The DMI reduction was mainly due to reduced DMI during the first meal following silage distribution $(P<0.10)$. Lower intake rates during this principal meal $(P<$ 0.05 ) suggested lower palatability of WAS. Addition of $\mathrm{NH}_{3}$ and amines to FAS did not alter milk yield, daily DMI or other variables of intake behaviour compared to the control FAS. In the rumen, a dilutive effect by amines was suggested. In this study, a direct role of $\mathrm{NH}_{3}$ and amines on feed intake regulation was not established.
\end{abstract}

\section{grass silage / dairy cow / intake / ammonia / amine}

Résumé - Influence de l'addition d'ammoniac et d'amines sur l'ingestion d'ensilage d'herbe et les activités alimentaires des vaches laitières. L'influence de l'addition d'ammoniac $\left(\mathrm{NH}_{3}\right)$ et d'amines (cadavérine, histamine, putrescine et tyramine) sur les quantités de matière sèche (MS) d'ensilage d'herbe volontairement ingérées et sur la production de lait a été étudiée sur 4 vaches laitières équipées d'une canule ruminale et produisant en moyenne $21 \mathrm{~kg}$ de lait par jour. Quatre régimes différents ont été étudiés : un ensilage sans consenvateur (WAS), un ensilage conservé avec de l'acide formique $(4,5 \mathrm{l} / t)$, préparé à partir du même fourrage (FAS), FAS additionné juste avant sa distribution aux animaux de $2,9 \mathrm{~g}$ de $\mathrm{NH}_{3} / \mathrm{kg} M S$ (FAS $+N$ ) et FAS additionné de $2,8 \mathrm{~g}$ d'amines $/ \mathrm{kg} M S$ (FAS $\left.+A\right)$. Dans 3 essais successifs de type cross-over, les régimes WAS, FAS + N et FAS + A ont été comparés à l'ensilage FAS. Les animaux ont reçu, à volonté, les ensilages une fois par jour, et recevaient en

† Present address: DLO-Institute for Animal Science and Health (ID-DLO), PO Box 160, 8200 AD Lelystad, The Netherlands.

* Correspondence and reprints. 
outre $5,5 \mathrm{~kg}$ de MS d'aliment concentré équilibré par jour pour couvrir leurs besoins. Seul l'ensilage WAS, qui contenait une concentration élevée en $\mathrm{NH}_{3}$, amines et acides gras volatils (tableau II), a été moins bien ingéré (soit $-0,8 \mathrm{~kg}$ de MS par jour, $\mathrm{P}<0,10$ ) que l'ensilage $F A S$, lequel était relativement bien conservé. Les animaux ont alors produit $2 \mathrm{~kg}$ de lait en moins chaque jour (tableau III). La diminution de quantité ingérée observée s'explique surtout par une réduction de la durée $(\mathrm{P}<0,10)$ et de la quantité ingérée lors du grand repas suivant la distribution d'ensilage $(-1,5 \mathrm{~kg}$ de $M S, P<0,10)$. Elle est, cependant, compensée partiellement par l'ingestion supérieure lors de petits repas $(+1,3$ repas et $+0,7$ de MS ingérée, différence non significative). Une vitesse d'ingestion plus faible $(P<0,05)$ lors du grand repas suggère en outre une appétibilité plus faible de l'ensilage WAS par rapport à FAS et donc une diminution des qualités organoleptiques. L'addition d'ammoniac et d'amines à l'ensilage FAS n'a modifié ni les quantités de MS ingérées d'ensilage, ni les paramètres du comportement alimentaire, ni la production de lait par rapport à l'ensilage témoin FAS. Avec l'ensilage WAS, le pH du contenu ruminal ainsi que la teneur en $\mathrm{NH}_{3}$ ont été plus élevés qu'avec $F A S$, mais ces facteurs ne semblent pas impliqués dans l'ingestion plus faible de l'ensilage WAS. Un effet des amines sur l'augmentation de la quantité de liquide dans le rumen est suggéré, mais, dans cette étude, le rôle direct de l'ammoniac et des amines sur la régulation de la quantité ingérée d'ensilage d'herbe n'est pas démontré.

ensilage d'herbe / vache laitière / ingestion / ammoniaque / amines

\section{INTRODUCTION}

In temperate regions, grass silage has become an important forage in rations for dairy cattle. Feed intake and animal performance on silage-based diets, however, depend highly on preservation quality of the silage (Waldo, 1978; Jarrige et al, 1982), which is determined by the content of fermentation end-products (Dulphy and Demarquilly, 1981). Correlations between fermentation products in silage and intake indicate acetic acid and ammonia $\left(\mathrm{NH}_{3}\right)$ as products involved in intake reduction of low quality silages in cattle (Rook and Gill, 1990), and also in sheep (Demarquilly, 1973; Dulphy and Michalet-Doreau, 1981). It is also suggested that other products of protein fermentation (eg, amines) are involved in intake reduction (Hole, 1985a; Baile and Della-Ferra, 1988), by negatively affecting taste and odour or influencing the chemostatic regulation of feed intake. The objective of the present experiment was to quantify the effect of $\mathrm{NH}_{3}$ and amines in the currently observed intake reduction of low quality silages in dairy cows, by adding these products to a good quality silage, with low concentrations of fermentation products.

\section{MATERIAL AND METHODS}

\section{Dietary treatments}

Two direct-cut grass silages were prepared in June 1991 from the first-cut of a single sward of cocksfoot (Dactylis glomerata) meadow. The grass was separated into 2 batches and ensiled either without additive (WAS) or with addition of $(4.5 / / t)$ formic acid (FAS). Four dietary treatments were tested: silages WAS and FAS without any addition; FAS with addition of $2.9 \mathrm{~g} \mathrm{NH}_{3}$ per $\mathrm{kg}$ dry matter (DM) (FAS +N); and FAS with addition of $2.8 \mathrm{~g}$ amines per $\mathrm{kg}$ DM (FAS $+\mathrm{A})$. The amine addition consisted of a mixture of the 4 biogenic amines: cadaverine $(0.6 \mathrm{~g})$, histamine $(0.5 \mathrm{~g})$, putrescine $(0.7 \mathrm{~g})$ and tyramine $(1.0 \mathrm{~g})$. The amines, as hydrochlorides salt, and the $\mathrm{NH}_{3}$ solution ( $20 \%$ Normapur ${ }^{T M}$ ) were purchased from Sigma Chimie, Saint-Quentin-Fallavier, France and Prolabo, Paris, France, respectively.

The composition and fermentation characteristics of the 4 studied silage diets are given in table I. Although FAS was analyzed in each individual cross-over experiment, only the average values are given here, because of similarity of the results. The silage FAS could be qualified as well preserved (Dulphy and Demarquilly, 1981) with low $\mathrm{pH}$, low $\mathrm{NH}_{3}-\mathrm{N}$ content and only small quantities of volatile fatty acids (VFA) and amines. However, some butyric acid (on average $3 \mathrm{~g} / \mathrm{kg}$ DM) was found. In contrast to FAS, WAS could be 
Table I. Composition and fermentation characteristics ( $\mathrm{g} / \mathrm{kg} \mathrm{DM}$, unless stated otherwise) of the dietary silage treatments.

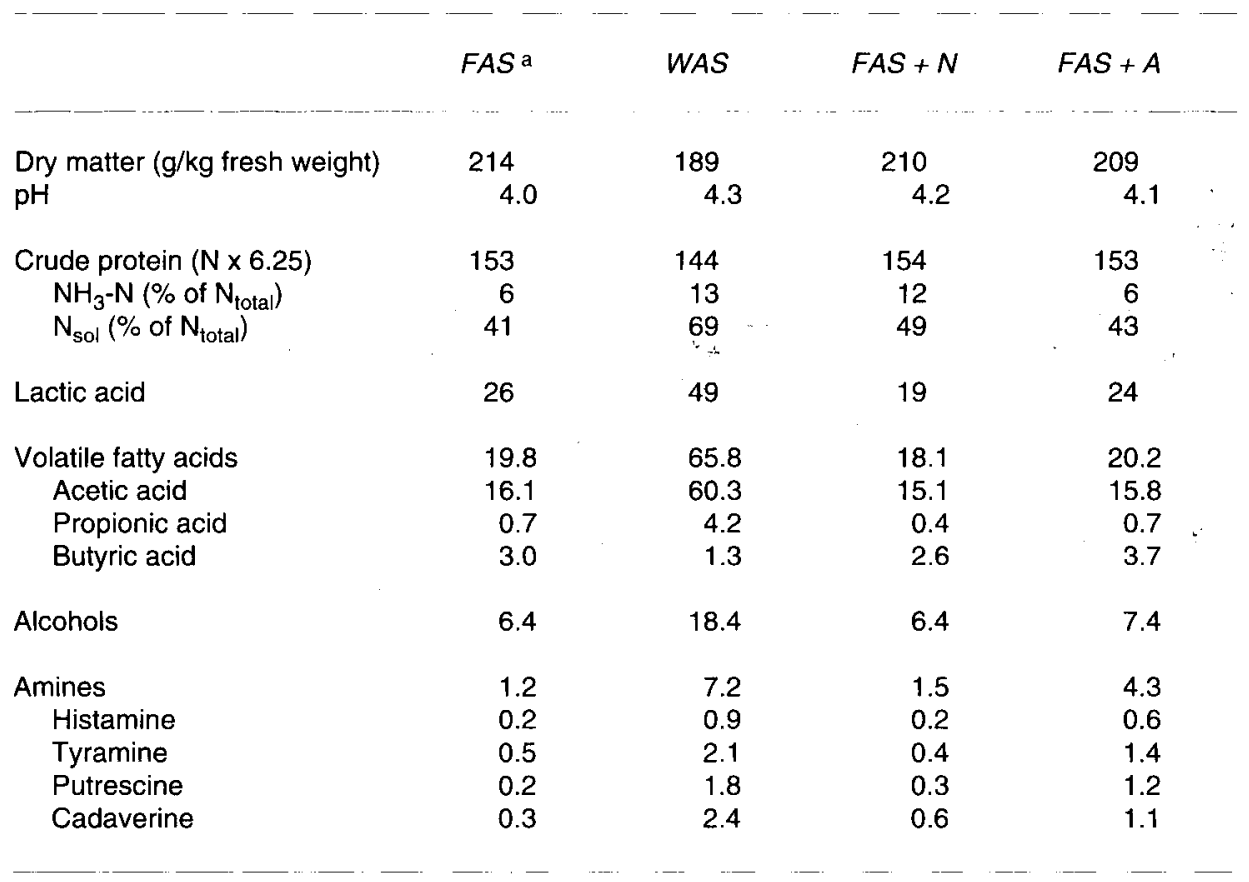

a Average value of individual results of FAS in Exp I, II and III. FAS: formic-acid-preserved silage; WAS: direct-cut silage without additive; FAS + N: FAS with addition of $2.9 \mathrm{~g} \mathrm{NH}_{3} / \mathrm{kg} \mathrm{DM}$; FAS + A: FAS with addition of $2.8 \mathrm{~g}$ amine/kg DM.

considered as a medium to poorly preserved silage, indicated by higher $\mathrm{NH}_{3}-\mathrm{N}$ and soluble $\mathrm{N}$ and higher concentrations of amines and VFAs, but with low levels of butyric acid. The increase of $\mathrm{NH}_{3}-\mathrm{N}$ in $\mathrm{FAS}+\mathrm{N}$ and amine concentrations in $\mathrm{FAS}+\mathrm{A}$ were due to $\mathrm{NH}_{3}$ and amine addition to FAS, respectively. The feeding values of the 2 basic silages, derived from INRA feed tables (Andrieu et al, 1989), were, for energy, 0.89 UFL $/ \mathrm{kg}$ DM for WAS and 0.88 UFL $\mathrm{kg}$ DM for FAS, and, for absorbable protein, $63 \mathrm{PDIE} / \mathrm{kg}$ DM for WAS and 74 PDIE/kg DM for FAS. It was assumed that $\mathrm{NH}_{3}$ and amine addition did not significantly alter UFL and PDIE values.

Prior to feeding, daily required quantities of WAS and FAS were removed from the silo, followed by preparation of FAS $+\mathrm{N}$ or FAS $+\mathrm{A}$. Detailed procedures of diet preparation and product addition have been published elsewhere (Van Os et al, 1995).

\section{Animals, feeding and experimental design}

Four Holstein dairy cows (average live weight $610 \pm 42 \mathrm{~kg}$ ) were used. At the beginning of the experiment they were in the 7 th week of lactation. The animals were fitted with permanent rumen cannulae. Throughout the experiment, the animals were kept in an experimental unit, artificially lit for $11 \mathrm{~h}$ a day. Silages were offered to the cows from January through April 1992. The animals were fed ad libitum ( $10 \%$ refusals) with a single distribution of feed per day $(11.00 \mathrm{~h})$. To meet nutritional requirements, $5.5 \mathrm{~kg} \mathrm{DM}$ of a commercial concentrate (net energy, $1.05 \mathrm{UFL} / \mathrm{kg}$ $\mathrm{DM}$ and absorbable protein, $115 \mathrm{PDIE} / \mathrm{kg} \mathrm{DM}$ ) was offered daily plus $190 \mathrm{~g}$ of a mineral mixture ( $14 \% \mathrm{P}, 16 \% \mathrm{Ca}, 3 \% \mathrm{Mg}$ ), both given separately from silage. The daily schedule of concentrate 
and silage distribution and milking is described in table II. Animals had free access to water and salt blocks throughout the entire experiment.

The study was divided into 3 sequential $2 \times 2 \times 4$ cross-over designs in which the dietary treatments WAS, FAS $+\mathrm{N}$ and FAS + A were compared to the control FAS (Experiment (Exp) I, comparing WAS to FAS; Exp II, comparing FAS + $\mathrm{N}$ to FAS; and Exp III, comparing FAS + A to FAS). Exp I consisted of 2 experimental periods of 3 weeks each. In the first 2 weeks, animals were adapted to the silage, and in the third week measurements were made. Exp II and III consisted of 2 periods each of 2 weeks, with the first week for diet adaptation and the second for measurements.

\section{Measurements and sampling}

During periods of measurements, samples of the distributed silage were taken daily, and analyzed for DM content. From this daily sampling, a pooled sample of fresh material was stored frozen until analysis for total nitrogen $(\mathrm{N})$, amine content and fermentation products.

Daily dry matter intake (DMI) was calculated throughout the experiment as the difference between distributed amount and refusal. Intake behaviour was monitored during 5 consecutive days using continuously weighed mangers and signals of jaw movements were simultaneously recorded by a submandibular foam-filled balloon. Weight variations of the mangers and air-pressure signals from the balloon were recorded continuously by a microcomputer. The calculation of initial and final intake rates of the principal meal (first meal-after silage distribution) was described by Baumont et al (1990).

On 2 consecutive days, while recording intake behaviour, rumen fluid was withdrawn continuously $(100 \mathrm{ml} / \mathrm{h})$ from the ventral region of the reticulorumen, using a peristaltic pump (Ismatec SA, Laboratoriumstecknick, Switzerland). Rumen fluid samples $(50 \mathrm{ml})$ were collected every halfhour from $10.30 \mathrm{~h}$ until $13.30 \mathrm{~h}$. All samples were stored and the sample of this series that corresponded with the time of termination of the principal meal (determined from data of intake behaviour recording), was analyzed for $\mathrm{pH}, \mathrm{NH}_{3}$, VFA and amines. Two additional samples were taken at $14.30 \mathrm{~h}$ and $16.00 \mathrm{~h}$. In the samples of rumen fluid, $\mathrm{pH}$ was measured immediately, whereas samples for $\mathrm{NH}_{3}$, VFA and amine determination were preserved and stored at $-20^{\circ} \mathrm{C}$ until analysis.

Milk production was measured daily and samples were taken for analysis of fat, protein and lactose content twice a week.

\section{Chemical analysis}

Silage DM content was determined by oven drying $\left(48 \mathrm{~h}\right.$ at $\left.80^{\circ} \mathrm{C}\right)$ and corrected for volatile components (Dulphy et al, 1975). Fermentation characteristics $\left(\mathrm{pH}\right.$, organic acids, alcohols, $\mathrm{NH}_{3}$ and soluble nitrogen $\left(\mathrm{N}_{\text {sol }}\right)$ ) were determined in liquid pressed from the silage, whereas amines were extracted from the fresh material by maceration in trichloroacetic acid $(10 \%)$. Total $\mathrm{N}$ and $\mathrm{N}_{\text {sol }}$ were determined by the Kjeldahl method, $\mathrm{NH}_{3}$ by gas diffusion (Conway, 1957), and lactic

Table II. Daily feeding and milking schedule.

Time of day (h)

Activity

07.00

07.30

11.00

16.00

\section{Milking}

Refusal collection of previous day;

Concentrate $(2.25 \mathrm{~kg} \mathrm{DM})$ and mineral distribution

Silage distribution

Milking;

Concentrate (2.25 kg DM) and mineral distribution 
acid by the enzymatic method described by Noll (1974). Alcohols and VFA were analyzed by gaschromatography (Jouany, 1981) and rumen fluid $\mathrm{NH}_{3}-\mathrm{N}$ was determined according the method of Berthelot adapted by Van Eenaeme et al (1969). Amines were analyzed by HPLC (Van Os et al, 1995).

\section{Statistical analysis}

Within each cross-over design, data were subjected to analysis of variance by the general linear model procedure of the SAS Institute Inc (1987). Effects of dietary treatment (1 df), period $(1 d f)$ and animals ( $3 d f)$ were included in the model.

\section{RESULTS}

\section{Daily intake, intake behaviour and rumination}

Average silage DMl during days of recording feed intake behaviour $(n=5)$, and variables of intake behaviour and rumination are given in table III. Compared to FAS, a significant reduction in DMl of $0.8 \mathrm{~kg}$ was observed for WAS, whereas DMI of FAS + N and FAS + A did not differ from FAS. Dietary treatments did not affect daily time spent eating, which averaged 336 min (eating time for concentrate

Table III. Intake behaviour a and rumination.

$\frac{\text { Exp I }}{\text { FAS WAS SEM }} \frac{\text { Exp II }}{\text { FAS FAS }+N \text { SEM }} \frac{\text { Exp III }}{\text { FAS FAS + A SEM }}$

\begin{tabular}{|c|c|c|c|c|c|c|c|c|c|}
\hline \multicolumn{10}{|l|}{ Day } \\
\hline DMI & 12.2 & $11.4^{*}$ & 0.2 & 12.0 & 12.6 & 0.6 & 12.4 & 12.5 & 0.7 \\
\hline Duration & 335 & 349 & 12 & 322 & 339 & 17 & 342 & 327 & 20 \\
\hline Intake rate & 37 & 34 & 1 & 38 & 38 & 2 & 36 & 39 & 3 \\
\hline \multicolumn{10}{|l|}{ Principal meal } \\
\hline DMI & 3.3 & $1.8^{*}$ & 0.3 & 3.1 & 3.3 & 0.2 & 3.2 & 3.1 & 0.2 \\
\hline Duration & 62 & $48^{*}$ & 3 & 64 & $71^{\star \star \star}$ & 2 & 70 & 64 & 9 \\
\hline Intake rate & 54 & $38^{\star \star}$ & 2 & 50 & 47 & 2 & 46 & 49 & 6 \\
\hline Initial & 79 & 68 & 4 & 78 & 77 & 4 & 68 & 74 & 4 \\
\hline Final & 36 & 29 & 2 & 33 & 32 & 2 & 37 & 35 & 9 \\
\hline \multicolumn{10}{|l|}{ Small meals } \\
\hline Number & 9.2 & 10.5 & 0.5 & 9.0 & 8.9 & 0.2 & 8.9 & 9.2 & 1.6 \\
\hline Intake rate & 32 & 31 & 1 & 35 & 35 & 2 & 34 & 36 & 3 \\
\hline \multicolumn{10}{|l|}{ Rumination } \\
\hline Duration & 526 & 533 & 11 & 513 & 528 & 21 & 512 & 535 & 24 \\
\hline Duration cycle & 61 & $65^{\star \star}$ & 1 & 62 & $60^{* *}$ & 1 & 59 & $61^{*}$ & 1 \\
\hline Lag time b & 22 & 25 & 5 & 26 & 21 & 3 & 19 & 22 & 3 \\
\hline \multicolumn{10}{|l|}{ Mastication } \\
\hline Duration & 861 & 882 & 6 & 835 & 867 & 30 & 854 & 862 & 41 \\
\hline Efficiency & 14.3 & $13.1^{\star}$ & 0.3 & 14.6 & 14.6 & 0.1 & 14.6 & 14.5 & 2.3 \\
\hline
\end{tabular}

a DMI, dry matter intake $(\mathrm{kg})$; duration (min); rumination cycle $(\mathrm{s})$; intake rate $(\mathrm{g} \mathrm{DM} / \mathrm{min})$; efficiency (g DM/min mastication). b Start of first rumination after end of principal meal (min). SEM, standard error of means (4 df). Significance of the difference with the corresponding control FAS $\left({ }^{*} P<0.05,{ }^{\star \star} P<0.10\right)$. 
being excluded). During the principal meal, the DMI of FAS, FAS + N and FAS + A was similar and averaged $3.2 \mathrm{~kg}$ ( $26 \%$ of daily silage DMI). For WAS, DMI was $16 \%$ of daily silage DMI and was lower $(P<0.10)$ than for FAS, as a result of the combination of a shorter duration of the principal meal $(P<$ $0.01)$ and the lower intake rate $(P<0.05)$. The latter seemed to be reduced during the whole meal, because no significant differences were observed in intake rates during the initial and final phases of the principal meal. For FAS + N, compared with FAS, only duration of the principal meal was prolonged $(P<0.05)$, whereas other variables of intake behaviour were similar. In Exp III, no difference in intake behaviour was observed between FAS and FAS + A. The average number of small meals was 9.0 for diets FAS, $\mathrm{FAS}+\mathrm{N}$ and $\mathrm{FAS}+\mathrm{A}$, and was slightly higher (+1.5) for WAS.

The treatments did not affect time spent ruminating, which averaged 525 min per day. Compared with FAS, rumination cycles were significantly longer for WAS (+4 s; $P<$ $0.05)$ and for FAS + A (+2 s; $P<0.01)$, but shorter $(-2 \mathrm{~s} ; P<0.05)$ for FAS $+\mathrm{N}$. The rumination lag time, ie duration of interval between end of principal meal and initiation of rumination, was similar for the 4 dietary treatments. Daily duration of mastication was similar for the 4 silages ( $860 \mathrm{~min}$ ), but resulted in combination with the lower intake of WAS in a significant lower mastication efficiency ( $\mathrm{g} \mathrm{DM} / \mathrm{min}$ mastication) of WAS compared to FAS.

\section{Intake and animal performance}

Silage DMI during the total period of measurements (average of $7 \mathrm{~d}$ ) of milk production and the resulting average energy and protein balances are given in table IV. The silage DMI of WAS was $11.7 \mathrm{~kg}$ per day, was the same on days of intake and rumi-

Table IV. Daily dry matter intake (DMI), milk production and average energy and protein balances.

\begin{tabular}{|c|c|c|c|c|c|c|c|c|c|}
\hline & \multicolumn{3}{|c|}{ Exp I } & \multicolumn{3}{|c|}{ Exp II } & \multicolumn{3}{|c|}{ Exp III } \\
\hline & FAS & WAS & $S E M$ & FAS & $F A S+N$ & SEM & FAS & $F A S+A$ & SEM \\
\hline \multicolumn{10}{|l|}{$\mathrm{DMI}(\mathrm{kg})$} \\
\hline Silage & 12.5 & $11.7^{\star}$ & 0.2 & 12.5 & 12.7 & 0.3 & 12.4 & 12.5 & 0.4 \\
\hline Concentrate & 5.5 & 5.5 & - & 5.5 & 5.5 & - & 5.5 & 5.5 & - \\
\hline \multicolumn{10}{|l|}{ Milk production } \\
\hline & 23.8 & 21.8 & 1.4 & 20.2 & 20.6 & 0.3 & 19.9 & 20.6 & 1.1 \\
\hline $\mathrm{kg} \mathrm{FCM}$ & 23.9 & 21.7 & 1.4 & 19.6 & 20.6 & 0.6 & 19.9 & 21.1 & 1.3 \\
\hline Energy ingested a & 16.8 & 16.2 & & 16.8 & 16.8 & & 16.8 & 16.8 & \\
\hline Energy balance & +1.2 & +1.6 & & +3.1 & +2.7 & & +3.0 & +2.4 & \\
\hline Protein ingested $\mathrm{b}$ & 1558 & 1370 & & 1558 & 1558 & & 1558 & 1558 & \\
\hline Protein balance & +11 & -72 & & +218 & +184 & & +203 & +145 & \\
\hline
\end{tabular}

a Ingested net energy in UFL, including 5.8 UFL from concentrate (UFL, feed unit for lactation, with 1 UFL is equivalent to $7.1 \times 10^{6} \mathrm{~J}$ (Vermorel, 1989)). ${ }^{\circ}$ Ingested absorbable protein in $\mathrm{g}$ PDIE, including 633 PDIE from concentrate (PDIE, rumen undegraded protein plus microbial protein from rumen degraded organic matter). SEM, standard error of means $(4 d f)$. ${ }^{*}$ Significantly different $\left({ }^{*} P<0.10\right)$ with the corresponding control (FAS). 
nation behaviour recordings and was significantly lower $(P<0.10)$ than FAS. Daily $\mathrm{DMI}$ of $\mathrm{FAS}+\mathrm{N}$ and $\mathrm{FAS}+\mathrm{A}$ was similar to that of FAS. Besides silage, cows consumed $5.5 \mathrm{~kg}$ DM of concentrate per day.

The average milk production during the 3 cross-over experiments was $21.1 \mathrm{~kg}$ FCM (table IV). In Exp I, a non-significant decrease of $2.2 \mathrm{~kg}$ FCM was observed for WAS compared to FAS, whereas no differences were observed in Exp II and III. Average energy and protein balances per dietary treatment were calculated as the difference between energy and protein ingested from silage and concentrate and requirements for maintenance and production. These balances indicate that with all dietary treatments the cows covered their energy requirements. Absorbable protein supply was largely sufficient in Exp II and III, but was marginal for FAS and insufficient for WAS in Exp I.

\section{Rumen fluid characteristics}

The course of rumen $\mathrm{pH}$ up to $5 \mathrm{~h}$ after silage distribution is given in figure 1. After the end of the principal meal a comparable $\mathrm{pH}$ drop of about 0.5 units was observed for FAS, FAS + N and FAS + A. The drop was less for WAS (0.2 units), resulting in a significant difference in rumen $\mathrm{pH}$ between WAS and FAS at the end of the principal meal. During the observation period, rumen $\mathrm{pH}$ remained relatively constant for WAS, whereas for the other 3 treatments the $\mathrm{pH}$ drop after the principal meal was followed by a gradual increase. In Exp II, at all sampling times, rumen $\mathrm{pH}$ was not significantly different for FAS and FAS + N, while in Exp III it was higher $(P<0.10)$ for $\mathrm{FAS}+\mathrm{A}$, before silage distribution and at $14.30 \mathrm{~h}$.

During the principal meal, rumen fluid $\mathrm{NH}_{3}$ concentrations increased for all dietary treatments (fig 2). At the end of the meal, it was higher $(P<0.05)$ for FAS $+\mathrm{N}$, whereas at $14.30 \mathrm{~h}$ and $16.00 \mathrm{~h}$ concentrations were similar to those for FAS. In contrast to the general course of rumen $\mathrm{NH}_{3}$ concentrations for FAS, FAS + N and FAS + A, a continuing increase over $5 \mathrm{~h}$ was observed for WAS. With this diet, $\mathrm{NH}_{3}$ concentrations were generally higher $(+32 \mathrm{mg} / \mathrm{l}$ on aver-
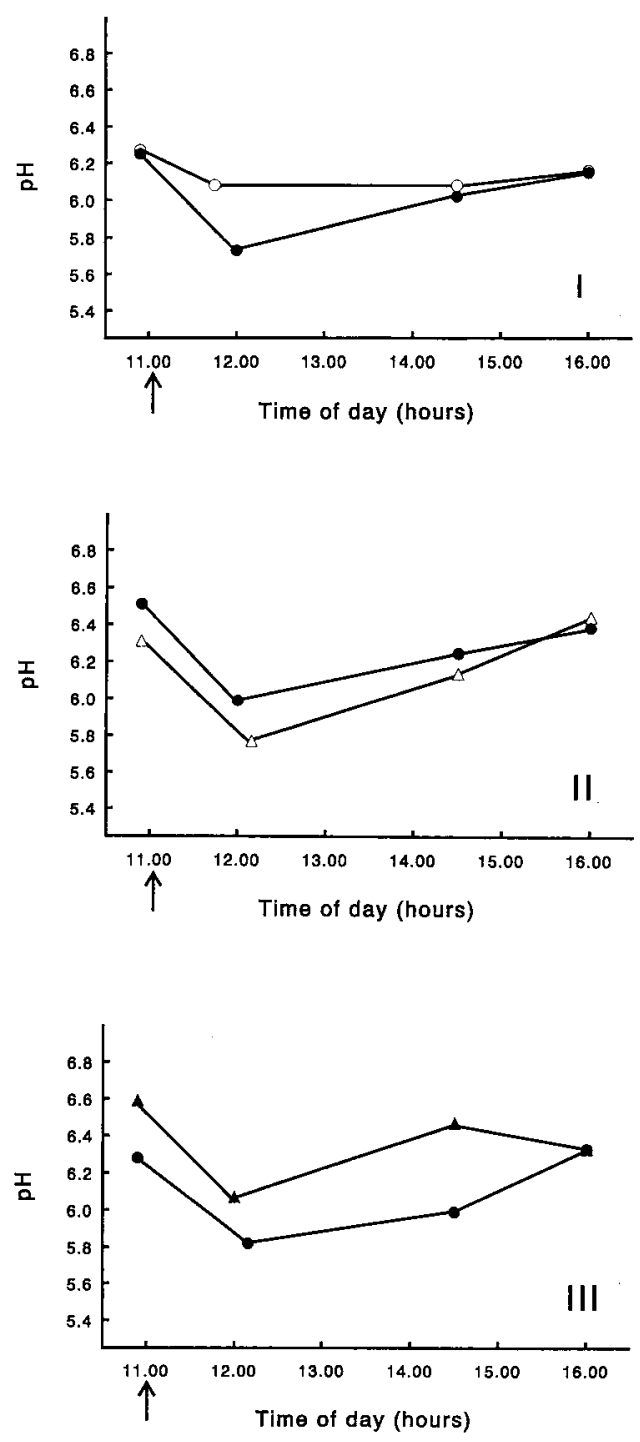

Fig 1. Time course of ruminal $\mathrm{pH}$ in Exp I, II and III. $\uparrow$ Silage distribution. Diets: O WAS; FAS; $\Delta$ $\mathrm{FAS}+\mathrm{N} ; \triangle \mathrm{FAS}+\mathrm{A}$. 
age over the 4 sampling times) and significantly different from FAS at $16.00 \mathrm{~h}$ $(P<0.01)$. Rumen $\mathrm{NH}_{3}$ concentrations with FAS + A did not differ from those observed for FAS.
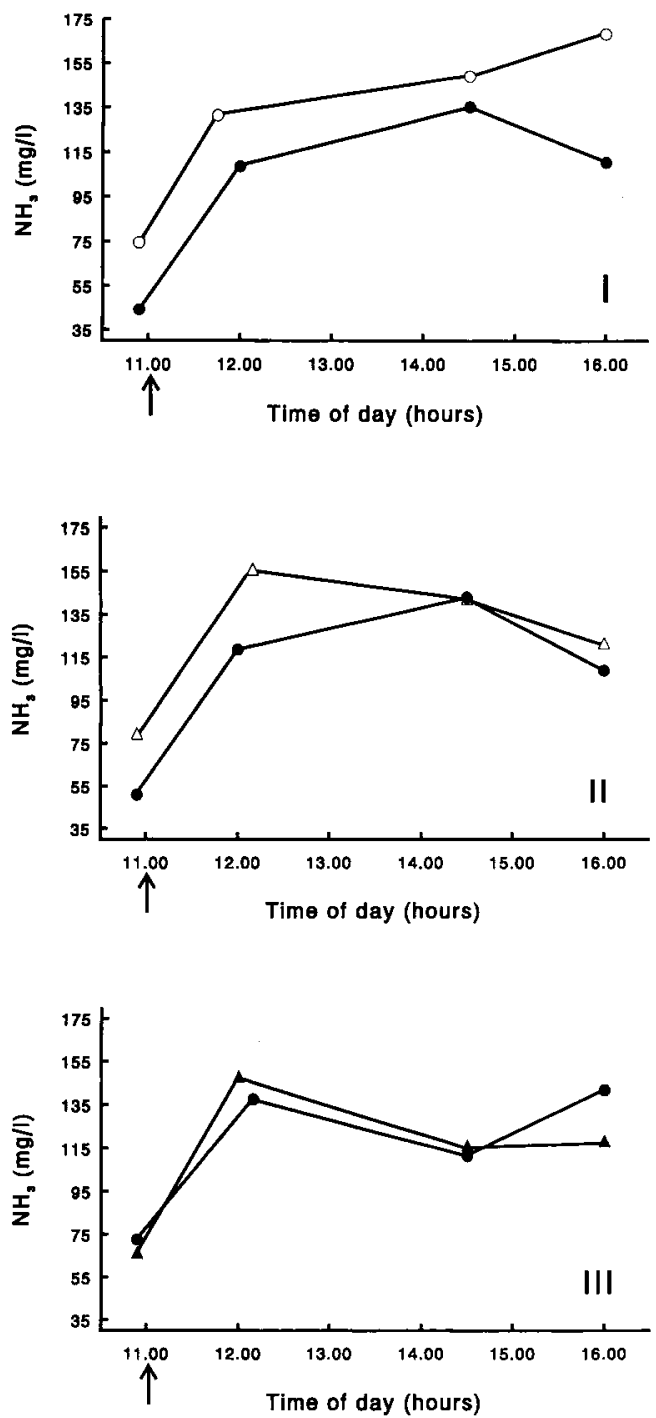

Fig 2. Time course of ruminal $\mathrm{NH}_{3}$ concentrations in Exp I, II and III. $\uparrow$ Silage distribution. Diets: O WAS; $\odot$ FAS; $\triangle$ FAS + N; $\triangle$ FAS + A.
The increase of total rumen fluid VFA concentrations over the principal meal was relatively low and ranged from $7 \mathrm{mmol} / /$ for WAS to 27 for FAS + N (fig 3). Significant differences were never observed between
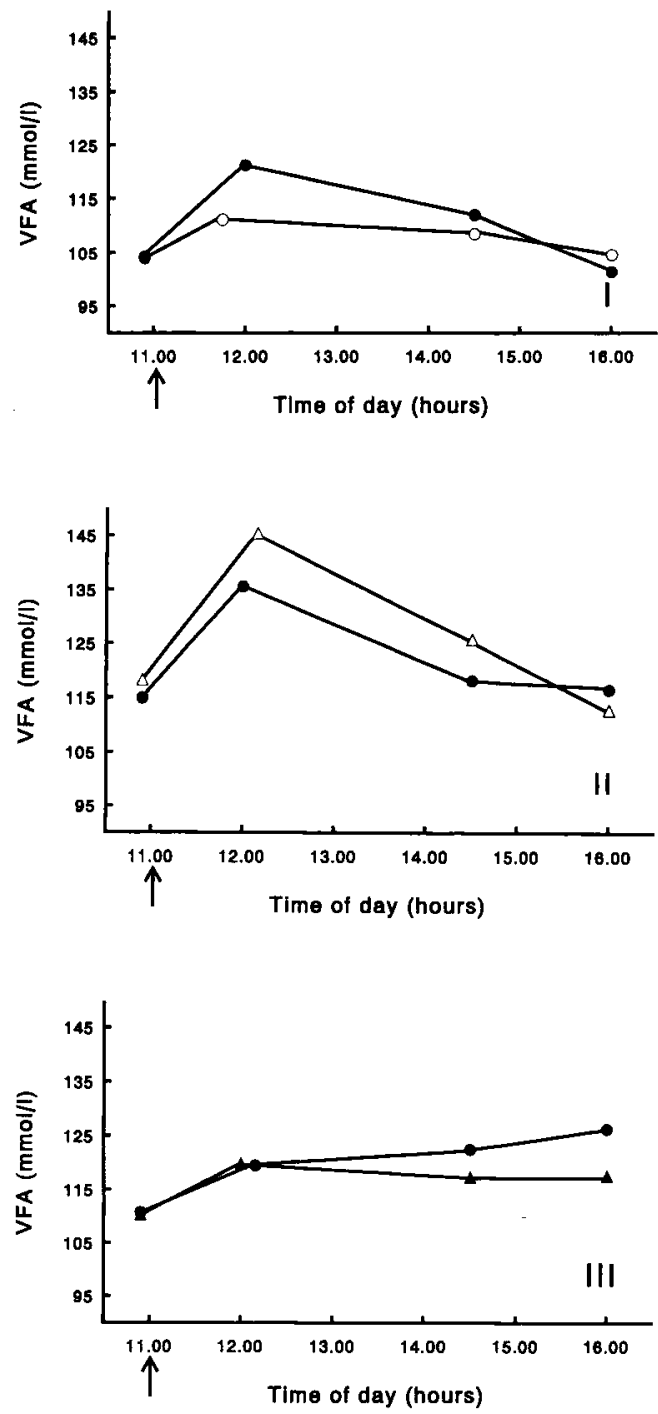

Fig 3. Time course of ruminal volatile fatty acid concentrations in Exp I, II and III. $\uparrow$ Silage distribution. Diets: O WAS; - FAS; $\triangle$ FAS + N; $\triangle$ FAS + A. 
the diets WAS, FAS + N, FAS + A and their corresponding control FAS at the end of the principal meal or at other sampling times. However, the greatest difference in rumen VFA concentration was found in Exp II, being on average $10 \mathrm{mmol} / \mathrm{l}$ higher for $\mathrm{FAS}+\mathrm{N}$, during the $4 \mathrm{~h}$ following silage distribution. Proportional VFA composition was similar for the treatments FAS, FAS + N and $F A S+A$, without large shifts during the sampling period and averaged $67.4 \%$ for acetic acid, $17.8 \%$ propionic acid, $11.8 \%$ butyric acid and $2.7 \%$ for valeric acid. For WAS, however, the proportion of propionic acid $(18.9 \%)$ was higher $(P<0.10)$ and butyric acid $(9.8 \%)$ was lower $(P<0.05)$ than the proportions observed in FAS. For all treatments, the rumen liquid after the principal meal contained no histamine and only traces ( $<20 \mathrm{mg} / \mathrm{l}$ ) of tyramine, putrescine and cadaverine.

\section{DISCUSSION}

\section{Silage quality}

The prepared silages WAS and FAS were similar in DM content, $\mathrm{pH}$ and crude protein. The low concentrations of fermentation products $\left(\mathrm{NH}_{3}\right.$, VFA, alcohols and amines) in FAS indicated that it was well preserved (Dulphy and Demarquilly, 1981). Concentrations of $\mathrm{NH}_{3}$ and acetic acid in FAS corresponded with those in the silages used for intake studies by Waldo (1978) and Dulphy and Michalet-Doreau (1981). In contrast, the relatively high concentrations of $\mathrm{NH}_{3}-\mathrm{N}$, acetic acid and amines indicated a more extensive fermentation in WAS, resulting in a lower silage quality. Its $\mathrm{NH}_{3}-\mathrm{N}$ content was intermediate to the low and high quality silages used by the authors previously mentioned, whereas acetic-acid content was higher. Generally, the chemical composition of WAS was similar to the untreated silages cited by Dulphy and Lienard (1981) (characteristics: $\mathrm{pH}, 4.26 ; \mathrm{NH}_{3}$ $\mathrm{N}, 10.1 \%$ of $\mathrm{N}_{\text {total; }}$ acetic acid, $51 \mathrm{~g} / \mathrm{kg} \mathrm{DM}$ and butyric acid, $4.4 \mathrm{~g} / \mathrm{kg} \mathrm{DM}$ ). Total and individual amine concentrations of WAS were within the range of values found by Tveit et al (1992). Addition of $\mathrm{NH}_{3}$ to FAS increased $\mathrm{NH}_{3}-\mathrm{N}$ concentration in $\mathrm{FAS}+\mathrm{N}$ up to the level found in WAS, whereas the quantity of amines finally added to FAS was insufficient to reach concentrations found in WAS (Van Os et al, 1995). Nevertheless, amine concentrations in FAS + A were in the lower part of the range of those found in grass silages preserved with little or no formic acid (Hole, 1985b; Tveit et al, 1992).

\section{Intake, intake and rumination behaviour and performance}

Compared to FAS, higher concentrations of fermentation products in WAS led to lower daily DMI. This DMI reduction $(0.8 \mathrm{~kg})$ was close to the $1.0 \mathrm{~kg}$ observed in data compiled by Dulphy and Lienard (1981). Milk yield reduction, however, was larger in the present experiment $(2.2 \mathrm{~kg} \mathrm{FCM} / \mathrm{d})$ than in literature $(0.9 \mathrm{~kg} \mathrm{FCM} / \mathrm{d}$; Dulphy and Lienard, 1981). The slightly higher negative response in milk yield was possibly due to the shorter measuring period ( $7 \mathrm{~d}$ in the present study). Consequently, less or no time was left for recovery from a possible decrease in milk yield due to the diet change-over by increased intake after habituation to the other diet or mobilisation of body reserves. The overall reaction of cows (lower intake and milk production) to a lower quality silage was thus confirmed, although the differences in milk production in our study were not significant due to the limited number of animals.

The addition of $\mathrm{NH}_{3}$ or amines had no negative effects on DMI and milk yield. Moreover, in sheep, addition of $\mathrm{NH}_{3}$ to a well-preserved silage had no effect, 
whereas DMI tended to be lower when amines were added (Van Os et al, 1994). The latter was not confirmed in the present experiment. These results imply that the correlation between reduced intake and increased silage $\mathrm{NH}_{3}$ content (Demarquilly, 1973; Dulphy and Michalet-Doreau, 1981; Rook and Gill, 1990) is not due to $\mathrm{NH}_{3}$ per se. The results also agree with the absence of negative effects on intake and animal performance when cattle were offered $\mathrm{NH}_{3}$ treated hay, with considerable residual $\mathrm{NH}_{3}$ content (Drennan, 1990). Data on direct effects of amines on silage intake are scarce and deal mainly with short-term effects. Intraruminal infusions of tyramine did not decrease intake in dairy cows (Thomas et al, 1963), whereas infusion of a single dose of $100 \mathrm{~g}$ putrescine in the rumen reduced subsequent silage intake and milk yield (Lingaas and Tveit, 1992). It is likely that the influence of amines on silage intake depends on type and quantity used. Buchanan-Smith and Phillip (1986), for instance, found lower intake in sheep during the meal following ruminal infusion of a combination of histamine, putrescine, cadaverine, and tyramine.

The principal mechanisms controlling the intake of precision chopped silages are oropharyngeal reactions of the animals (taste, smell) and chemostatic regulation (satiation) (Gill et al, 1986), whereas rumen fill seems to be of minor importance (Deswysen and Ehrlein, 1981; Chiofalo et al, 1992; Thiago et al, 1992a). The action of chemostatic regulation and oro-pharyngeal factors is mainly revealed during the principal meal. The spontaneous end of the principal meal will be initiated by the achievement of a certain state of satiation, caused by the rise of metabolite concentrations in the rumen or blood circulation. Involvement of oro-pharyngeal factors can be established by alterations in average intake rate of the meal and especially from alterations in the initial intake rate (Van Os et al, 1995).
Nearly identical eating behaviour of cows offered FAS + N and FAS + A compared to FAS demonstrated once again that the added $\mathrm{NH}_{3}$ and amines had no effect on intake regulation. No differences were found in daily intake rate, DMI and intake rate during the principal meal, variables which are normally highly affected by silage quality (Dulphy et al, 1984; Chiofalo et al, 1992). For WAS, however, a rapid achievement of satiation was observed during the principal meal, expressed by the significantly lower intake and the shorter time spent eating $(P<$ $0.10)$. Lower intake rates for WAS during the whole meal and in the beginning and end phase, indicate its lower palatability. Compared to FAS, the DMI of WAS during the principal meal was only $55 \%$ in our experiment versus $70 \%$ by heifers in the experiments of Dulphy et al (1984). This extra reduction of DMI may be attributed to additional effects on satiation of the preceding concentrate gift. The lower intake of WAS during the principal meal was partly compensated by a small increase in number of small meals during the day. So the abovementioned intake regulation mechanisms may have less effect on DMI during a larger time span.

Unequal amine content in FAS + A and WAS did not allow us to state precisely their role in intake regulation. However, an identical quantity of amines added to the same silage FAS $(2.8 \mathrm{~g} / \mathrm{kg}$ DM) resulted in a slightly lower intake in sheep, presumably caused by oro-pharyngeal influences (Van Os et al, 1995). Although cattle seem to be more sensitive to silage quality than sheep (Dulphy et al, 1984), the effect of silage quality may be overruled by a high intake motivation of the lactating cows to meet their nutritional requirements, indicated by the positive net energy balances for all dietary treatments, even with WAS. The deficit of absorbable protein with this silage, however, is more probably a consequence of the lower intake than a direct cause. The higher metabolite turnover rates in produc- 
ing animals may therefore have reduced treatment effects on intake.

The effects of fermentation products on rumination behaviour were negligible and physiological importance of the differences in duration of the rumination cycles may be questioned.

\section{Rumen fluid characteristics}

Rumen fluid $\mathrm{pH}, \mathrm{NH}_{3}$ and VFA concentrations corresponded to ranges of the fermentation characteristics given by Bosch et al (1992). At the end of the principal meal, the lowest $\mathrm{pHs}$ were found for the silages with highest intake. Higher $\mathrm{pH}$ values with small fluctuations for WAS may indicate that rumen acidity could not be considered as a factor that limits intake in this study. However, the slightly higher rumen $\mathrm{pH}$ during a great part of the measuring period for FAS + A was remarkable. This was also observed in sheep (Van Os et al, 1995) and attributed to a possible diluting effect in the rumen. The dilution effect, however, could not be established from $\mathrm{NH}_{3}$ and VFA concentrations, perhaps because concentrate distribution altered rumen VFA and $\mathrm{NH}_{3}$ concentrations and their relationships to one another markedly, compared to those in sheep offered silage only (Van Os et al, 1995).

The role of rumen $\mathrm{NH}_{3}$ concentration in rapid achievement of satiation with WAS was also unlikely, because equal silage intakes were observed during the principal meal and throughout the day for FAS $+\mathrm{N}$ and FAS, despite higher $\mathrm{NH}_{3}$ content in the rumen with $F A S+N$. The influence of the higher rumen $\mathrm{NH}_{3}$ content $5 \mathrm{~h}$ after WAS distribution may be expected, but generally the concentrations will decrease (Thiago et al, 1992b; Van Os et al, 1995) and even higher intakes per kg metabolic weight were found in dairy heifers with rumen $\mathrm{NH}_{3}$ concentrations above $200 \mathrm{mg} / \mathrm{l}$ (Teller et al,
1989). The earlier decrease of rumen $\mathrm{NH}_{3}$ with FAS + N compared to WAS can be attributed to a higher $\mathrm{NH}_{3}$ utilization rate for microbial growth, because a better equilibrium of energy and $N$ is generally present in formic acid preserved silages (Chamberlain and Choung, 1993).

Enhanced VFA concentrations and a slightly lower $\mathrm{pH}$ during a great part of the measuring period for FAS + $\mathrm{N}$ compared to FAS may indicate the increased microbial activity as a result of the extra nitrogen. Inversion of the average proportions of propionic and butyric acid in the rumen VFA pool for WAS can be explained by the difference in fermentation characteristics compared with the FAS-based diets. The higher lactic acid content in WAS will increase rumen propionate concentrations, whereas less butyric acid will be formed caused by its lower residual sugar content (Chamberlain and Choung, 1993).

The presence of only traces of amines in the rumen, even of cows offered WAS containing considerable quantities of amines, indicates a fast disappearance of amines. This is possibly due to a considerable dilution that occurs when silage amines enter the rumen and to degradation of amines in the rumen. Degradation of histamine by rumen microorganisms was observed in sheep by Kay and Sjaastad (1974) and it is likely that degradation of other types of amines also occurs.

In conclusion, the hypothesis of possible negative effects of $\mathrm{NH}_{3}$ and amines on silage DMI were not confirmed here. Evidently, $\mathrm{NH}_{3}$ per se is not a cause for intake reduction of low quality silages, like WAS. It is probably caused by the combination of high $\mathrm{NH}_{3}$ content and other fermentation products (organic acids and alcohols) and the low availability of residual sugars that characterise poor quality silages. The influence of amines on intake control must be verified by higher additions to the animal diets. 


\section{ACKNOWLEDGMENTS}

This work is part of a PhD project of MVO of the Wageningen Agricultural University, The Netherlands (Dept of Human and Animal Physiology), supported by the French Institut National de la Recherche Agronomique (INRA) and the Dutch Dienst Landbouwkundig Onderzoek (DLO). It is a part of a cooperative research project with the DLO-Research Institute for Livestock Feeding and Nutrition (IVVO-DLO) Lelystad, The Netherlands. The authors are grateful to $B$ Lassalas and G Hervouët for analytical assistance and A Ollier and his staff for animal care.

\section{REFERENCES}

Andrieu J, Demarquilly C, Sauvant D (1989) Tables of feed used in France. In: Ruminant Nutrition, Recommended allowances and feed tables (R Jarrige, ed) John Libbey Eurotext, London, UK, 213-303

Baile CA, Della-Ferra MA (1988) Physiology of control of food intake and regulation of energy balance in dairy cows. In: Nutrition and Lactation in the Dairy Cow (PC Garnsworthy, ed) Butterworths, London, UK, 251-261

Baumont R, Seguier N, Dulphy JP (1990) Rumen fill, forage palability and alimentary behaviour in sheep. $J$ Agric Sci Camb 115, 277-284

Bosch MW, Tamminga S, Post G, Leffering CP, Muylaert JM (1992) influence of stage of maturity of grass silages on digestion processes in dairy cows. 1 . Composition, nylon bag degradation rates, fermentation characteristics, digestibility and intake. Livest Prod Sci 32, 245-264

Buchanan-Smith JG, Phillip LE (1986) Food intake in sheep following intraruminal infusion of extracts from lucerne silage with particular reference to organic acids and products of protein degradation. J Agric Sci Camb 106, 611-617

Chamberlain DG, Choung $J J$ (1993) The nutritional value of grass silage. In: Proc of the 10th International Conference on Silage Research (P O'Kiely, M O'Connell, J Murphy, eds) Dublin City University, Dublin, Ireland, 131-136

Chiofalo V, Dulphy JP, Baumont R (1992) Influence of the method of forage conservation on feeding behaviour, intake and characteristics of the reticulorumen content in sheep fed ad libitum. Reprod Nutr Dev 32, 377.392

Conway EJ (1957) Microdiffusion Analysis and Volumetric Error. Crosby Lockwood \& son Ltd, London, UK, 468
Demarquilly C (1973) Composition chimique, caractéristiques fermentaires, digestibilité et quantité ingérée des ensilages de fourrages : modifications par rapport au fourrage vert initial. Ann Zootech 22, 1-35

Deswysen AG, Ehrlein HJ (1981) Silage intake, rumination and pseudo-rumination activity in sheep studied by radiography and jaw movement recordings. $\mathrm{Br}$ J Nutr 46, 327-335

Dulphy JP, Demarquilly C, Henry M (1975) Perte de composés volatils lors de la détermination à l'étuve de la teneur en matière sèche des ensilages. Ann Zootech 24, 743-756

Dulphy JP, Demarquilly C (1981) Problèmes particuliers aux ensilages. In: Prévision de la Valeur Nutritive des Aliments des Ruminants, INRA-publications, Versailles, France, 81-104

Dulphy JP, Lienard G (1981) Effet de l'acide formique sur la valeur alimentaire des ensilages directs d'herbe destinés aux vaches laitières; conséquences économiques. Bull Tech CRZV Theix INRA 44, 33-40

Dulphy JP, Michalet-Doreau B (1981) Prévision de l'ingestibilité des ensilages d'herbe. In: Prévision de la valeur nutritive des aliments des ruminants, INRApublications, Versailles, France, 169-184

Dulphy JP, Michalet-Doreau B, Demarquilly C (1984) Étude comparée des quantités ingérées et du comportement alimentaire et mérycique d'ovins et de bovins recevant des ensilages d'herbe réalisés selon différentes techniques. Ann Zootech 33, 291-320

Drennan MJ (1990) Ammonia treatment of roughage. 1. Effects on straw and hay digestibility, voluntary intake and performance of heifers. Ir J Agric Res 29, 15-22

Gill M, Thiago LRS, Buchanan-Smith JG (1986) Intake problems associated with ensiled forages. In: Feed Intake by Beef Cattle. Miscellaneous Publication No. 121, Oklahoma State University, OK, USA, 341-352

Hole RJ (1985a) The nutritive value of silage made from Poa pratensis spp alpigena and Phleum pratense. II. Lactating dairy cows fed silage made from first cut of Poa pratensis or Phieum pratense. Scientific Reports of the Agricultural University of Norway (No 231) 64, $1-20$

Hole RJ (1985b) The nutritive value of silage made from Poa pratensis ssp alpigena and Phleum pratense. V. Amines in silage made from first cut of Poa pratensis or Phleum pratense. Scientific Reports of the Agricultural University of Norway (No 234) 64, 1-9

Jarrige R, Demarquilly C, Dulphy JP (1982) Forage conservation. In: Nutritional Limits to Animal Production from Pastures (JB Hacker, ed) Commonwealth Agricultural Bureaux, Farnham Royal, UK, 363-387

Jouany JP (1981) Dosages des acides gras volatils et des alcools dans les ensilages par chromatographie en phase gazeuse. Bull Tech CRZV Theix INRA 46, 63-66 
Lingaas F, Tveit B (1992) Etiology of acetonemia in Norwegian cattle. 2. Effect of butyric acid, valeric acid and putrescine. J Dairy Sci 75, 2433-2439

Kay RNB, Sjaastad $\varnothing \mathrm{V}$ (1974) Absorption and catabolism of histamine in sheep. J Physiol 243,79 99

Noll F (1974) Methods of Enzymatical Analysis (Bergmeyer HU, ed) Academic Press, New York, USA, 1475-1477

Rook AJ, Gill M (1990) Prediction of the voluntary intake of grass silages by beef cattle 1 . Linear regression analyses. Anim Prod 50, 425-438

SAS Institute Inc (1987) SAS/STAT, Guide for Personal Computers. Version 6, SAS Ins Inc, Cary NC, USA

Teller E, Vanbelle M, Kamatali P, Wavreille J (1989) Intake of direct cut or wilted grass silage as related to chewing behaviour, ruminal characteristics and site and extent of digestion by heifers. J Anim Sci $67,2802-2809$

Thiago LRS, Gill M, Sissons JW (1992a) Studies of method of conserving grass herbage and frequency of feeding cattle. 2. Eating behaviour, rumen motility and rumen fill. Br J Nutr 67, 319-336

Thiago LRS, Gill M, Dhanoa MS (1992b) Studies of method of conserving grass herbage and frequency of feeding cattle. 1. Voluntary feed intake, digestion and rate of passage. Br J Nutr 67, 305-318

Thomas JW, Moore LA, Okamoto M, Sykes JF (1963) A study of factors affecting rate of intake of heifers fed silage. J Dairy Sci 46, 1471-1483

Tveit B, Lingaas F, Svendsen M, Sjaastad ØV (1992) Etiology of acetonemia in Norwegian cattle. 1. Effect of ketogenic silage, season, energy level and genetic factors. J Dairy Sci 75, 2421-2432

Van Eenaeme C, Bienfait JM, Lambot O, Pondant A (1969) Détermination automatique de l'ammoniaque dans le liquide du rumen par la méthode de Berthelot adapté à l'auto-analyseur. Ann Med Vet 7, 419-429

Van Os M, Dulphy JP, Baumont R (1995) The effect of protein degradation products in grass silages on feed intake and intake behaviour in sheep. Br J Nutr (in press)

Vermorel M (1989) Energy: the feed unit systems. In: Ruminant Nutrition, Recommended Allowances and Feed Tables (R Jarrige, ed), John Libbey Eurotext, London, UK, 23-30

Waldo DR (1978) The use of direct acidification in silage production. In: Fermentation of Silage. A Review (ME McCullough, ed), National Feed Ingredients Association, USA, 117-182 